\title{
HISTAMINE RELEASE AND ENDOTOXIN SHOCK IN THE PRIMATE*
}

\author{
By LERNER B. HINSHAW, $\dagger$ MARGARET M. JORDAN AND JAMES A. VICK \\ (From The Department of Physiology, University of Minnesota, Minneapolis, Minn.)
}

(Submitted for publication March 16, 1961 ; accepted May 5, 1961)

There is a growing interest in the pathogenesis and treatment of endotoxin shock as this type of shock becomes increasingly important in medical and surgical practices (1-4). Recent work has described the hemodynamic effect of endotoxin in the dog which is characterized by a sudden and severe hypotension following administration of a lethal dose of endotoxin $(5,6)$. Previous reports from this laboratory $(7-10)$ have extended the earlier observations, and specific attempts have been made to gain an understanding of the basic mechanisms underlying the development of the irreversible phase of this type of shock (9-16). An extension of these studies has ascertained the degree of species variation in endotoxin shock $(17,18)$, and major differences have been noted between the hemodynamic responses of the dog and monkey.

Recent reports have suggested the prominent role of histamine in endotoxin shock in animals other than the primate $(14,19-23)$. The release of histamine in anaphylaxis has also been described $(24,25)$ with similarities noted between the vascular actions of histamine and endotoxin $(8-10,13,26-31)$. A recent finding by Schayer $(20,21)$ has indicated an increase in histidine decarboxylase activity after endotoxin administration and in other forms of stress.

The purpose of the present investigation was to assess a variety of changes in the monkey, previously demonstrated in other species after endotoxin administration. Of primary interest are changes in blood histamine and histidine and the ultimate effects of their release in the primates. Results of this study confirm the view that histamine plays a crucial role in shock due to endo-

* This research was supported by grants from the Minnesota Heart Association and the United States Public Health Service (H-5023).

$\dagger$ Research performed during term of Lederle Medical Faculty Award, 1959-1962. Present address: Aeromedical Research Institute, Federal Aviation Agency, Univ. of Oklahoma (North Campus), Norman, Ok1. toxin and extend the suggestions of Schayer to include the basic mechanism of histamine release.

\section{METHODS}

Eight adult male and female monkeys of the Cynopithecoid group, Cercocebus torquatus Atys (Sooty Mangabey) were used in the present investigation. Animals weighed between 5.7 and $11.0 \mathrm{~kg}$ and were first anesthetized with ether followed by a suitable intravenous injection of sodium pentobarbital (Nembutal). The amount of Nembutal required to sustain anesthesia varied so that animals were maintained between planes 1 and 2 of the surgical stage by appropriate administration of the anesthetic. Blood samples from 6 monkeys were obtained from a catheter inserted into the femoral vein. and advanced to the inferior vena cava. Estimations for blood histamine ${ }^{1}$ and histidine ${ }^{2}$ were carried out and the procedures for the analyses have been described $(14,19)$. The following blood determinations were made in 4 animals before and after endotoxin administration: platelet and white blood cell counts $(32,33)$, blood-urea-nitrogen (BUN) $(34,35)$, and blood creatinine (36). Mean systemic arterial blood pressures were recorded by means of a Statham strain gage, and registered on a Sanborn direct-writing recorder. Determinations of hematocrits and blood $\mathrm{pH}$ were carried out on most animals coincident with electrocardiograph and heart rate recordings in several experiments. In 2 animals the following parameters were determined: mean systemic arterial pressure, portal venous pressure, heart rate, hematocrit and blood $\mathrm{pH}$. Lethal doses of Escherichia coli endotoxin (Difco), 5.2 to $13.0 \mathrm{mg}$ per $\mathrm{kg}$ (average, 8.9), were intravenously administered after sampling of blood for control determinations. All animals were dead within 30 hours (average, 6 hours) after endotoxin injection with the exception of Monkey 7 which was sacrificed at approximately 13 hours. Gross autopsies were made immediately after death and a variety of tissue samples was taken for histological analysis.

\section{RESULTS}

Figure 1 illustrates changes in mean systemic arterial blood pressure, hematocrit, blood $\mathrm{pH}$, histidine and histamine following injections of lethal doses of endotoxin in six monkeys. There was a variable effect on blood pressure, with all animals

1 2-(4-Imidazolyl)-ethylamine.

$2 \alpha$-Amino-4 (or 5) -imidazolepropionic acid. 


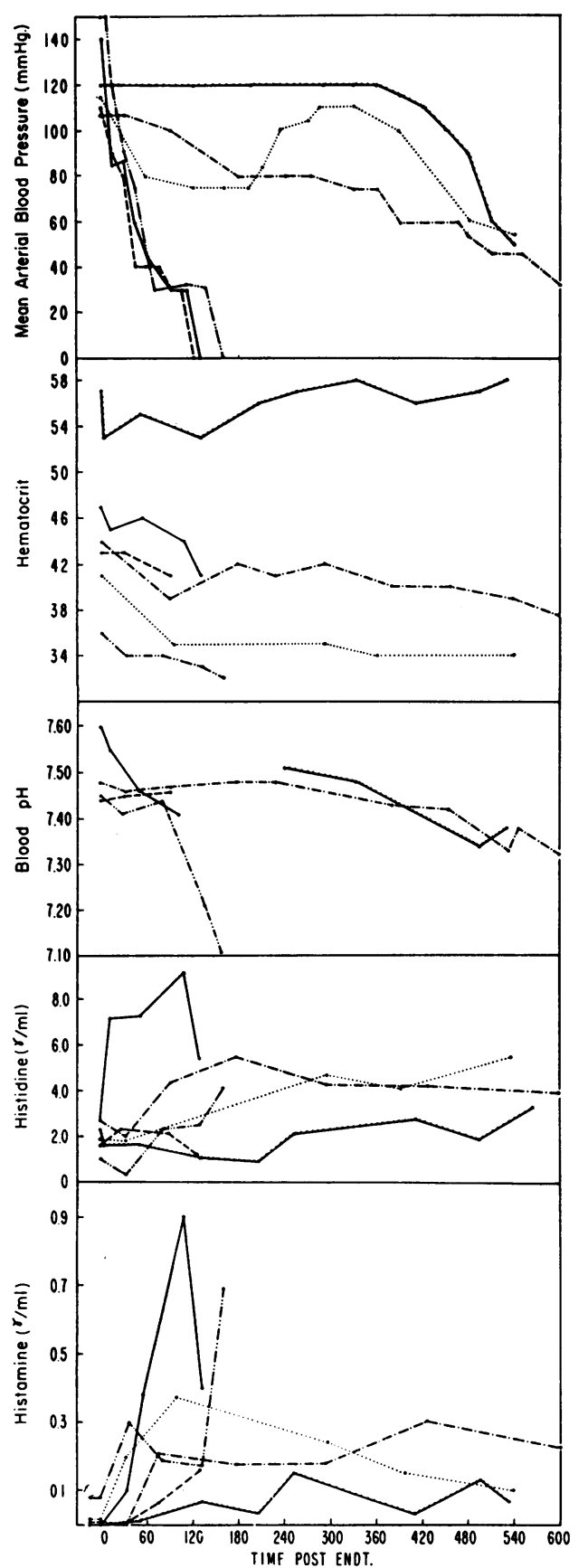

Fig. 1. Changes in mean systemic arterial blood PRESSURE, HEMATOCRIT, BLOOD PH, HISTIDINE AND HISTAMINE AFTER INJECTIONS OF LETHAL DOSES OF ENDOTOXIN IN SIX MONKEYS. Abscissa: time in minutes post endotoxin. Ordinate: animal $1 \mathrm{LLL} ; 2 \ldots \ldots ; 3 . . .7 ; 4$ -.--; $5-. .-; 6$
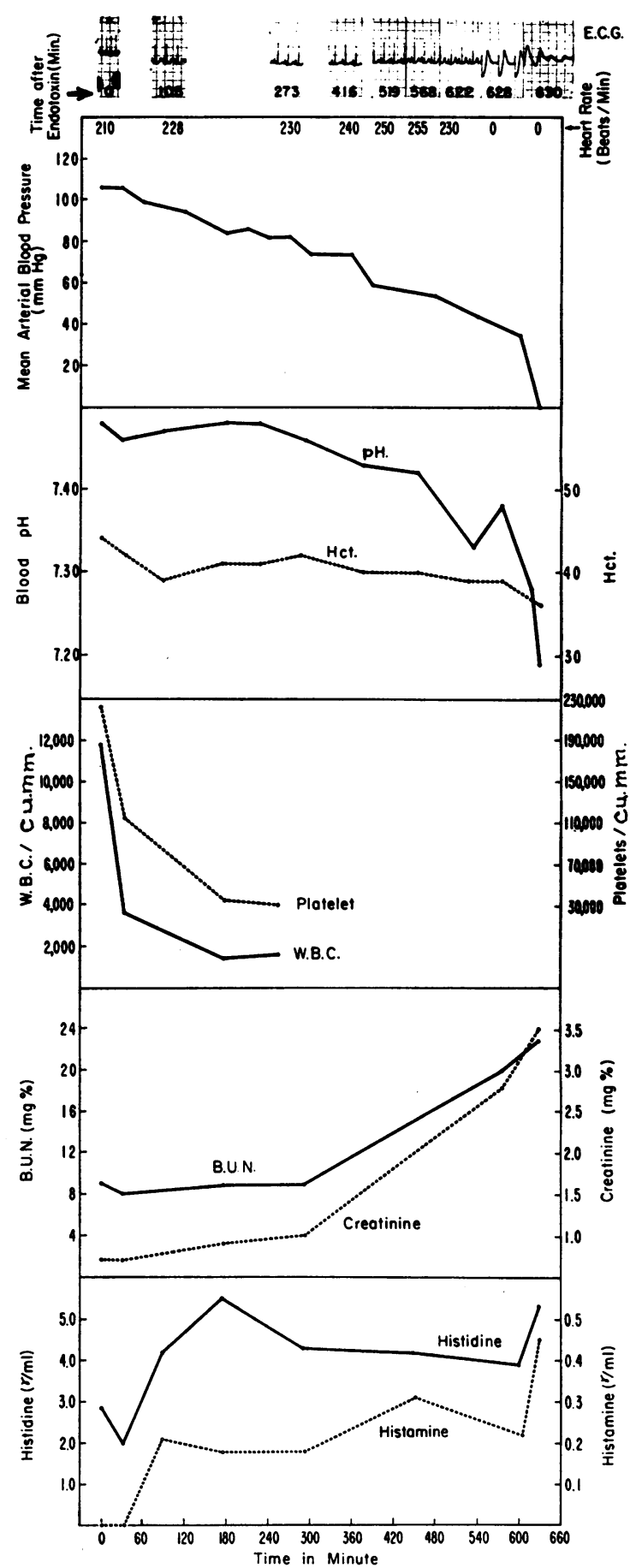

Fig. 2. Results from a typical experiment (MoNKeY 3). Abscissa: time in minutes post endotoxin. Ordinate: note ECG tracing in upper frame. Pre-endotoxin paper speed, $10 \mathrm{~mm} / \mathrm{sec}$; postendotoxin paper speed, $25 \mathrm{~mm} / \mathrm{sec}$ (time in minutes after endotoxin appears on each ECG section). 
TABLE I

Platelet and white blood cell counts, blood-urea-nitrogen and blood creatinine determinations in four monkeys given lethal doses of endotoxin

\begin{tabular}{|c|c|c|c|c|c|c|c|c|}
\hline \multirow[b]{2}{*}{ Determination } & \multirow{2}{*}{$\begin{array}{c}\text { Monkey } \\
\text { no. }\end{array}$} & \multirow[b]{2}{*}{ Control } & \multicolumn{6}{|c|}{ Time post endotoxin in minutes } \\
\hline & & & $0-60$ & $60-120$ & $120-180$ & $180-270$ & $270-420$ & $420-560$ \\
\hline Platelets $/ \mathrm{mm}^{3}$ & $\begin{array}{l}3 \\
4 \\
5 \\
6\end{array}$ & $\begin{array}{r}224,000 \\
196,000 \\
88,000 \\
234,000\end{array}$ & $\begin{array}{r}114,000 \\
56,000 \\
108,000\end{array}$ & $\begin{array}{r}96,000 \\
34,000 \\
118,000\end{array}$ & $\begin{array}{c}36,000 \\
* \\
17,000^{*} \\
{ }_{*}^{*}\end{array}$ & 32,000 & & \\
\hline $\begin{array}{l}\text { White blood } \\
\text { cells } / \mathrm{mm}^{3}\end{array}$ & $\begin{array}{l}3 \\
4 \\
5 \\
6\end{array}$ & $\begin{array}{l}11,800 \\
14,600 \\
27,500 \\
17,750\end{array}$ & $\begin{array}{l}3,550 \\
1,800 \\
4,700\end{array}$ & $\begin{array}{r}2,300 \\
10,000 \\
4,050\end{array}$ & $\begin{array}{c}1,400 \\
* \\
4, \underset{*}{350 *} \\
\end{array}$ & 1,600 & & \\
\hline $\begin{array}{l}\text { BUN } \\
(\mathrm{mg} \%)\end{array}$ & $\begin{array}{l}3 \\
4 \\
5 \\
6\end{array}$ & $\begin{array}{r}9 \\
11 \\
8 \\
14\end{array}$ & $\begin{array}{r}8 \\
13 \\
15\end{array}$ & $\begin{array}{l}16 \\
10 \\
17\end{array}$ & $\begin{array}{c}9 \\
17^{*} \\
11-12^{*} \\
*\end{array}$ & 9 & 20 & 23 \\
\hline $\begin{array}{l}\text { Blood creatinine } \\
(\mathrm{mg} \%)\end{array}$ & $\begin{array}{l}3 \\
4 \\
5 \\
6\end{array}$ & $\begin{array}{l}0.7 \\
1.6 \\
0.9 \\
1.2\end{array}$ & $\begin{array}{l}0.7 \\
1.8 \\
\\
1.5\end{array}$ & $\begin{array}{l}2.7 \\
1.3 \\
2.4\end{array}$ & $\begin{array}{l}0.9 \\
2.8^{*} \\
1.5^{*} \\
*\end{array}$ & 1.0 & 2.8 & 3.5 \\
\hline
\end{tabular}

* Death occurred during this time interval.

eventually becoming hypotensive within 8 hours after endotoxin. Hematocrits showed a steady decline except in Experiment 1 in which an early fall was followed by a return to the control value. The progressive development of acidosis was evident in most animals after endotoxin. Changes in blood histidine were variable, in most instances showing a significant rise above control values. All experiments demonstrated large increases of blood histamine, which became evident within the first hour after endotoxin injection.
Table I gives the values for platelet and white blood cell counts, BUN and creatinine for four of the six animals reported in Figure 1. There are marked decreases in platelet and white cell counts in all monkeys, although the time after endotoxin injection during which the lowest values were observed was variable. Significant increases in BUN and creatinine were observed in all animals within 1 to 2 hours after endotoxin administration.

Figure 2 designates the changes in a variety of parameters in Monkey 3. Steady decreases in

TABLE II

Blood pressures, heart rates, hematocrits and pH determinations in two monkeys given lethal doses of endotoxin

\begin{tabular}{|c|c|c|c|c|c|c|c|c|}
\hline \multirow[b]{2}{*}{ Measurement } & \multirow{2}{*}{$\begin{array}{c}\text { Monkey } \\
\text { no. }\end{array}$} & \multirow[b]{2}{*}{ Control } & \multicolumn{6}{|c|}{ Time post endotoxin in minutes } \\
\hline & & & $0-15$ & $15-30$ & $30-120$ & $120-240$ & $250-480$ & $480-780$ \\
\hline $\begin{array}{l}\text { Mean systemic arterial } \\
\text { blood pressure } \\
(\mathrm{mm} \mathrm{Hg})\end{array}$ & $\begin{array}{l}7 \\
8\end{array}$ & $\begin{array}{l}115 \\
110\end{array}$ & $\begin{array}{l}100 \\
100\end{array}$ & $\begin{array}{r}105 \\
90\end{array}$ & $\begin{array}{l}75 \\
37\end{array}$ & $\begin{array}{l}87 \\
30\end{array}$ & $\begin{array}{l}124 \\
18^{*}\end{array}$ & 117 \\
\hline $\begin{array}{l}\text { Portal venous pressure } \dagger \\
(\mathrm{mm} \mathrm{Hg})\end{array}$ & $\begin{array}{l}7 \\
8\end{array}$ & $\begin{array}{l}7.0 \\
7.0\end{array}$ & $\begin{array}{l}7.5 \\
8.0\end{array}$ & $\begin{array}{l}7.2 \\
7.0\end{array}$ & $\begin{array}{l}7.6 \\
7.0\end{array}$ & $\begin{array}{l}8.3 \\
6.5\end{array}$ & $\begin{array}{l}9.1 \\
7.7^{*}\end{array}$ & 9.8 \\
\hline $\begin{array}{l}\text { Heart rate } \\
\text { (beats } / \mathrm{min} \text { ) }\end{array}$ & $\begin{array}{l}7 \\
8\end{array}$ & $\begin{array}{l}185 \\
200\end{array}$ & $\begin{array}{l}190 \\
195\end{array}$ & $\begin{array}{l}190 \\
200\end{array}$ & $\begin{array}{l}207 \\
188\end{array}$ & $\begin{array}{l}202 \\
187\end{array}$ & $\begin{array}{l}204 \\
158^{*}\end{array}$ & 220 \\
\hline Hematocrit & $\begin{array}{l}7 \\
8\end{array}$ & $\begin{array}{l}47.5 \\
38.5\end{array}$ & $\begin{array}{l}48.0 \\
35.5\end{array}$ & & $\begin{array}{l}47.0 \\
37.0\end{array}$ & $\begin{array}{l}48.0 \\
37.0\end{array}$ & $\begin{array}{l}52.5 \\
37.0^{*}\end{array}$ & 54 \\
\hline Blood pH & $\begin{array}{l}7 \\
8\end{array}$ & 7.43 & $\begin{array}{l}7.41 \\
7.43\end{array}$ & & $\begin{array}{l}7.40 \\
7.42\end{array}$ & $\begin{array}{l}7.44 \\
7.36\end{array}$ & $\begin{array}{l}7.40 \\
7.14^{*}\end{array}$ & 7.35 \\
\hline
\end{tabular}

* Death occurred during this time interval.

† Portal venous pressures indicate maximal readings for the time indicated. 
TABLE III

Histological findings in five monkeys given lethal doses of endotoxin

\begin{tabular}{|c|c|c|c|c|c|}
\hline \multirow[b]{2}{*}{ Organ } & \multicolumn{5}{|c|}{ Monkey no. and sex } \\
\hline & $10^{7}$ & $2 \%$ & $3 \%$ & 49 & $5 \%$ \\
\hline Adrenal & Marked congestion & $\mathrm{N}$ & $\mathrm{N}$ & $\mathrm{N}$ & \\
\hline G.I. tract & $\mathrm{N}^{*}$ & $\mathrm{~N}$ & $\mathrm{~N}$ & $\mathrm{~N}$ & $\mathrm{~N}$ \\
\hline Heart & $\begin{array}{l}\text { Small vessels engorged; } \\
\text { one small area of hemorrhage }\end{array}$ & $\mathrm{N}$ & $\mathrm{N}$ & $\mathrm{N}$ & $\mathrm{N}$ \\
\hline Kidney & $\begin{array}{l}\text { Marked capillary and glo- } \\
\text { merular engorgement; in } \\
\text { some tubules cells swollen, } \\
\text { cytoplasm fluffy }\end{array}$ & $\mathrm{N}$ & $\mathrm{N}$ & $\begin{array}{l}\text { Early tubular } \\
\text { epithelial de- } \\
\text { generation } \\
\text { predominantly } \\
\text { in cortical } \\
\text { region }\end{array}$ & \\
\hline Liver & $\begin{array}{l}\text { Congested; no cellular al- } \\
\text { terations }\end{array}$ & $\mathrm{N}$ & $\mathrm{N}$ & $\mathrm{N}$ & $\begin{array}{l}\text { Multiple foci } \\
\text { round cell } \\
\text { infiltrate, } \\
\text { old }\end{array}$ \\
\hline Lung & Patchy cellular infiltrate & $\mathrm{N}$ & $\mathrm{N}$ & $\mathrm{N}$ & $\mathrm{N}$ \\
\hline Pancreas & & $\mathrm{N}$ & $\mathrm{N}$ & $\mathrm{N}$ & $\mathrm{N}$ \\
\hline Spleen & Congested & $\mathrm{N}$ & $\mathrm{N}$ & $\mathrm{N}$ & $\mathrm{N}$ \\
\hline $\begin{array}{l}\text { Time of death post } \\
\text { endotoxin ( } \mathrm{min})\end{array}$ & 840 & $\begin{array}{l}1,600 \\
\text { (est.) }\end{array}$ & 630 & 120 & 160 \\
\hline $\begin{array}{l}\text { Dose of endotoxin } \\
(\mathrm{mg} / \mathrm{kg})\end{array}$ & 13.0 & 5.2 & 10.4 & 10.1 & 10.0 \\
\hline
\end{tabular}

* Normal.

mean arterial pressure, blood $\mathrm{pH}$ and hematocrit are observed after injection of endotoxin. Sudden decreases in platelet and white cell counts are noted, while the blood levels of creatinine, BUN, histamine and histidine show marked increases during the 10 hour postendotoxin period. The electrocardiograph was normal until 622 minutes after endotoxin, just prior to death.

Table II lists a number of changes in two monkeys after administration of endotoxin. Animal 7 did not become hypotensive during the entire period of observation and was subsequently sacrificed. The second monkey exhibited a progressive decrease in arterial blood pressure with death occurring at approximately 7 hours. Portal venous pressures changed very little during the postendotoxin period. A progressive decrease in heart rate of Animal 8 was evident as hypotension developed. A slight degree of hemoconcentration was seen in Monkey 7, although changes in hematocrit in the second animal were negligible. A significant decrease in $\mathrm{pH}$ occurred in Monkey 8 .

All of the electrocardiograms were normal until just prior to death when the systemic blood pressure was extremely low.
The results of the histological sections are shown in Table III. The differences seen in the sections of Monkey 1 may be associated with respiratory difficulty and cyanosis, noted after induction of anesthesia, which were corrected by intubation and aspiration of pulmonary secretions. No other consistent histologic changes were noted except those observed in the kidneys of two animals.

\section{DISCUSSION}

Role of histamine in endotoxin shock. The large increases of blood histamine reported in the present study may account for the progressive development of systemic hypotension observed in the monkey given a lethal dose of endotoxin. An increased blood level of histamine could act on the peripheral vasculature to effect a decrease in the total peripheral resistance. Vascular resistance is known to decrease in various vascular beds of the $\operatorname{dog}(9,10)$ after the injection of endotoxin. The present findings give further support for the role of histamine as a "shock toxin" $(20,21)$.

The mechanism of histamine release in endotoxin shock. It has recently been proposed by 
Schayer $(20,21)$ that the rate of histamine synthesis is accelerated in endotoxin shock because of the increased activity of histidine decarboxylase. The findings of the present study extend his view to account for the increase in histamine on the basis of a rise in histidine, which supports the concept that endotoxin induces new histamine synthesis. Previous work in dogs (19) has indicated that the progressive increase of the histamine: histidine ratio is related to the relative rates of formation, conversion and destruction of the two components in question. It is possible that a rise in plasma histamine has resulted because of the marked decrease in the numbers of circulating platelets and white blood cells (37, 38). Similar decreases have been reported in the dog administered endotoxin (22) and in various forms of shock in man and animals (39-41). Histamine may possibly be released from the bound form in whole blood to the circulating form in plasma $(25,42)$, and from tissue such as muscle (43) or lung (44), or from various other sources (37).

Species rariations in endotoxin shock. Major differences have been noted between the hemodynamic responses $(1,17,18)$ and histological findings (1) of the dog and monkey after injections of lethal doses of endotoxin. The gradual fall in systemic arterial pressure, the small increase in portal venous pressure and the postmortem tissue findings in the present series of monkeys were similar to those in monkeys of a different species $(1,18)$. These findings are in marked contrast to those observed in dogs $(5,6$, $45)$. The relative phylogenetic proximity of monkey to man gives added interest to the observations of gross species differences. The common hemolysis and hemoconcentration in dogs given lethal doses of endotoxin $(18,26-28)$ were not apparent in the monkeys of the present study. No cardiac abnormality was observed in the monkeys' electrocardiographic tracings until just prior to death, this observation being similar to that of dogs $(6)$.

Correlation with human bacteremic shock. Case studies of bacteremic shock in man have been reported (2-4). Similarities in the findings of the monkeys of the present study and those in man are evident. Kidney disturbances have been reported in man after infections due to gram- negative bacilli $(2,3)$. Renal dysfunctions have included anuria, oliguria, hematuria and uremia which are usually conceded to be precipitated by the effects of systemic hypotension and consequent renal ischemia (4). Findings suggestive of ischemic changes in the kidneys were noted in the present study, and this observation is consistent with changes seen in human bacteremic shock $(1-4,46-48)$. The finding of an elevated blood creatinine and BUN in man and monkey suggests that renal failure is common to both. Other similarities noted were changes in hematocrit and blood $\mathrm{pH}$. Further basic and clinical investigations are needed to provide a more thorough understanding of the intimate mechanism of bacteremic shock.

\section{SUMMARY}

The increasing interest in the pathogenesis and treatment of endotoxin shock has prompted the present investigation. Eight monkeys were given lethal doses of endotoxin and a number of parameters studied. Results indicate the prominent role of histamine in endotoxin shock and extend the suggestions of Schayer to include the basic mechanism of histamine release. Species variations were noted which stress the importance of the close phylogenetic proximity of monkey to man. Relationships between human and experimental bacteremic shock have been indicated.

\section{ACKNOWLEDGMENT}

Appreciation is expressed to Dr. Robert Hebbel, University of Minnesota Medical School, for the preparation of histological sections, and to Lorentz E. Wittmers, Susan O. Doty and Edmund L. Mallet for technical assistance.

\section{REFERENCES}

1. Gilbert, R. P. Mechanisms of the hemodynamic effects of endotoxin. Physiol. Rev. 1960, 40, 245.

2. Braude, A. I., Siemienski, J., Williams, D., and Sanford, J. P. Overwhelming bacteremic shock produced by gram-negative bacilli: A report of four cases with one recovery. Univ. Mich. med. Bull. 1953, 19, 23.

3. Braude, A. I., Williams, D., Siemienski, J., and Murphy, R. Shock-like state due to transfusion of blood contaminated with gram-negative bacilli: successful treatment with antibiotics and arterenol. A.M.A. Arch. intern. Med. 1953, 92, 75.

4. Martin, W. J., and Nichols, D. R. Bacteremic shock. Proc. Mayo Clin. 1956, 31, 333. 
5. MacLean, L. D., Weil, M. H., Spink, W. W., and Visscher, M. B. Canine intestinal and liver weight changes induced by E. coli endotoxin. Proc. Soc. exp. Biol. (N. Y.) 1956, 92, 602.

6. Weil, M. H., MacLean, L. D., Visscher, M. B., and Spink, W. W. Studies on the circulatory changes in the dog produced by endotoxin from gramnegative microorganisms. J. clin. Invest. 1956, 35, 1191.

7. Hinshaw, L. B., and Bradley, G. M. Alterations in kidney weight produced by Escherichia coli endotoxin. Amer. J. Physiol. 1957, 189, 329.

8. Kuida, H., Hinshaw, L. B., Gilbert, R. P., and Visscher, M. B. The effect of gram-negative endotoxin on the pulmonary circulation. Amer. J. Physiol. 1958, 192, 335.

9. Hinshaw, L. B., Gilbert, R. P., Kuida, H., and Visscher, M. B. Peripheral resistance changes and blood pooling after endotoxin in eviscerated dogs. Amer. J. Physiol. 1958, 195, 631.

10. Hinshaw, L. B., Bradley, G. M., and Carlson, C. H. The effect of endotoxin on renal function in the dog. Amer. J. Physiol. 1959, 196, 1127.

11. Hinshaw, L. B., Kuida, H., Gilbert, R. P., and Visscher, M. B. The influence of perfusate characteristics on the pulmonary vascular response to endotoxin. Amer. J. Physiol. 1957, 191, 293.

12. Hinshaw, L. B., Gilbert, R. P., Kuida, H., and Visscher, M. B. The effect of endotoxin on vascular reactivity to epinephrine in the isolated perfused dog forelimb and lung. Proc. Soc. exp. Biol. (N. Y.) 1958, 99, 684.

13. Gilbert, R. P., Hinshaw, L. B., Kuida, H., and Visscher, M. B. The effects of histamine, 5 hydroxytryptamine and epinephrine on pulmonary hemodynamics with particular reference to arterial and venous segment resistances. Amer. J. Physiol. 1958, 194, 165.

14. Hinshaw, L. B., Vick, J. A., Carlson, C. H., and Fan, Y. L. Role of histamine in endotoxin shock. Proc. Soc. exp. Biol. (N. Y.) 1960, 104, 379.

15. Thuong, N. K., Hinshaw, L. B., and Wittmers, L. E. Effect of carotid sinus denervation and vagotomy in endotoxin shock. Physiologist 1960, 3, 164.

16. Vick, J. A., and Hinshaw, L. B. Adrenergic and cholinergic-like effects of endotoxin on the cardiovascular system of the dog. Physiologist 1960, $3,170$.

17. Hinshaw, L. B., Gilbert, R. P., Kuida, H., and Visscher, M. B. Role of hepato-splanchnic pooling following lethal injection of endotoxin in the dog, cat, rabbit and monkey. Fed. Proc. 1958, 17, 71.

18. Kuida, H., Hinshaw, L. B., Gilbert, R. P., and Visscher, M. B. A species study on the vascular effects of endotoxin. Amer. J. Physiol. In press.

19. Hinshaw, L. B., Jordan, M. M., and Vick, J. A. The mechanism of histamine release in endotoxin shock. Amer. J. Physiol. 1961, 200, 987.
20. Schayer, R. W. Relationship of stress-induced histidine decarboxylase to circulatory homeostasis and shock. Science 1960, 131, 226.

21. Schayer, R. W. Relationship of induced histidine decarboxylase activity and histamine synthesis to shock from stress and from endotoxin. Amer. J. Physiol. 1960, 198, 1187.

22. Weil, M. H., and Spink, W. W. A comparison of shock due to endotoxin with anaphylactic shock. J. Lab. clin. Med. 1957, 50, 501.

23. Feldberg, W., and Kellaway, C. H. The liberation of histamine by staphylococcal toxin and mercuric chloride. Aust. J. exp. Biol. med. Sci. 1938, 16, 249.

24. Dragstedt, C. A. Anaphylaxis. Physiol. Rev. 1941, 21, 563 .

25. Waalkes, T. P., Weissbach, H., Bozicevich, J., and Udenfriend, S. Serotonin and histamine release during anaphylaxis in the rabbit. J. clin. Invest. 1957, 36, 1115.

26. Lillehei, R. C., and MacLean, L. D. The intestinal factor in irreversible endotoxin shock. Ann. Surg. 1958, 148, 513.

27. Aust, J. B. Distribution kinetics of various substances in endotoxin shock. Fed. Proc. 1959, 18, 5.

28. Spink, W. W., and Vick, J. A. An evaluation of plasma, metaraminol and hydrocortisone in experimental endotoxin shock. Circulat. Res. In press.

29. Dale, H. H. Croonian Lectures on Some Chemical Factors in the Control of the Circulation. Lect. I and III. Lancet 1929, pp. 1179, 1285.

30. Stead, E. A., Jr., and Warren, J. V. The effect of the injection of histamine into the brachial artery on the permeability of the capillaries of the forearm and hand. J. clin. Invest. 1944, 23, 279.

31. Haddy, F. J. The mechanism of histamine edema. Fed. Proc. 1959, 18, 62.

32. Pohle, F. J. The blood platelet count in relation to the menstrual cycle in normal women. Amer. J. med. Sci. 1939, 197, 40.

33. Richar, W. J., and Breakell, E. S. Evaluation of an electronic particle counter for the counting of white blood cells. Amer. J. clin. Path. 1959, 31, 384.

34. Skeggs, L. T., Jr. An automatic method for colorimetric analysis. Amer. J. clin. Path. 1957, 28, 311.

35. Marsh, W. H., Fingerhut, B., and Kirsch, E. Determination of urea nitrogen with the diacetyl method and an automatic dialyzing apparatus. Amer. J. clin. Path. 1957, 28, 681.

36. Folin, $\mathrm{O}$, and $\mathrm{Wu}, \mathrm{H}$. A system of blood analysis. J. biol. Chem. 1919, 38, 81.

37. Van Arsdel, P. P., and Beall, G. N. The metabolism and functions of histamine. A.M.A. Arch. intern. Med. 1960, 5, 194.

38. Graham, H. T., Lowry, O. H., Wheelwright, F., Lenz, M. A., and Parish, H. H., Jr. Distribution of histamine among leukocytes and platelets. Blood $1955,10,467$. 
39. Thomas, L. The physiological disturbances produced by endotoxins. Ann. Rev. Physiol. 1954, 16, 467.

40. Stetson, C. A. Studies on the mechanism of the Shwartzman phenomenon; certain factors involved in production of local hemorrhagic necrosis. J. exp. Med. 1951, 93, 489.

41. Tocantins, L. M. The mammalian blood platelet in health and disease. Medicine (Baltimore) 1938, 17, 155.

42. Gaddum, J. H. Free and conjugated histamine in Ciba Found. Symp. on Histamine, G. E. W. Wolstenholme and C. M. O'Connor,. Eds. Boston, Little, Brown, 1956, p. 36.

43. Kun, E. Effect of meningococcal endotoxin on histamine content of blood and tissues of rabbits. Proc. Soc. exp. Biol. (N. Y.) 1947, 66, 197.
44. Feldberg, W., and Keogh, E. V. Liberation of histamine from the perfused lung by staphylococcal toxin. J. Physiol. (Lond.) 1937, 90, 280.

45. MacLean, L. D., and Weil, M. H. Hypotension (shock) in dogs produced by Escherichia coli endotoxin. Circulat. Res. 1956, 4, 546.

46. Borden, C. W., and Hall, W. H. Fatal transfusion reactions from massive bacterial contamination of blood. New Engl. J. Med. 1951, 245, 760.

47. Bradley, S. E. in Shock and Circulatory Homeostasis. Trans. 1st Conf., H. D. Green, Ed. New York, Josiah Macy Jr. Foundation, 1952, p. 170.

48. Stevens, A. R., Jr., Legg, J. S., Henry, B. S., Dille, J. M., Kirby, W. M., and Finch, C. A. Fatal transfusion reactions from contamination of stored blood by cold growing bacteria. Ann. intern. Med. 1953, 39, 1228.

\section{CORRECTION}

On page 1133 of the article entitled "Inhibition of L-Thyroxine Monodeiodination by Thyroxine Analogs" by Frank C. Larson and Edwin C. Albright (J. clin. Invest. 1961, 40, 1132), three molar concentrations were omitted from Table I. The subheadings for columns 1,2 and 3 of the table under the heading, "Per cent inhibition with increasing molar concentrations," should have been " $10^{-7}, 3 \times 10^{-7}$ and $10^{-6}$," respectively. 